Arq. Bras. Med. Vet. Zootec., v.65, n.1, p.55-60, 2013

\title{
Species-specific nested PCR as a diagnostic tool for Brucella ovis infection in rams
}

\author{
[Nested PCR espécie-específica para o diagnóstico da infecção por Brucella ovis em carneiros] \\ L.F. Costa ${ }^{1}$, C.N. Nozaki ${ }^{1}$, N.S.C. Lira ${ }^{1}$, J.M.A.P. Antunes ${ }^{1}$, M.N. Xavier ${ }^{2}$, E.A. Costa ${ }^{2}$, \\ T.A. Paixão ${ }^{2}$, R.L. Santos ${ }^{2}$, J. Megid ${ }^{1 *}$ \\ ${ }^{1}$ Faculdade de Medicina Veterinária e Zootecnia - UNESP - Botucatu, SP \\ ${ }^{2}$ Escola de Veterinária - Universidade Federal de Minas Gerais - Belo Horizonte, MG
}

\begin{abstract}
The aim of the present study was to evaluate a species-specific nested PCR based on a previously described species-specific PCR for detection of $B$. ovis in semen and urine samples of experimentally infected rams. The performance of the species-specific nested PCR was compared with the results of a genus-specific PCR. Fourteen rams were experimentally infected with the Brucella ovis REO 198 strain and samples of semen and urine were collected every week up to 180 days post infection. Out of 83 semen samples collected, 42 (50.6\%) were positive for the species-specific nested PCR, and $23(27.7 \%)$ were positive for the genus-specific PCR. Out of 75 urine samples, 49 (65.3\%) were positive for the species-specific nested PCR, whereas 11 (14.6\%) were genus-specific PCR positive. Species-specific nested PCR was significantly more sensitive $(\mathrm{P}<0.001)$ than the genus-specific PCR in semen and urine from experimentally infected rams. In conclusion, the species-specific nested PCR developed in this study may be used as a diagnostic tool for the detection of B. ovis in semen and urine samples from suspected rams.
\end{abstract}

Keywords: Brucella ovis, species-specific, nested PCR, semen, urine

\section{RESUMO}

O presente estudo objetivou avaliar uma técnica de nested PCR espécie-específica delineada a partir de PCR espécie-específica descrita anteriormente para detecção de B. ovis em sêmen e urina de carneiros infectados experimentalmente. $O$ desempenho da nested PCR espécie-específica foi comparado com os resultados de uma PCR gênero-específica. Quatorze carneiros foram infectados experimentalmente com Brucella ovis REO 198 e amostras de sêmen e de urina foram colhidas semanalmente até 180 dias após a infecção. De 83 amostras de sêmen, 42 (50,6\%) foram positivas pela nested PCR espécie-específica, e 23 $(27,7 \%)$ foram positivas pela PCR gênero-específica. De 75 amostras de urina, 49 (65,3\%) foram positivas pela nested PCR espécie-específica, enquanto 11 (14,6\%) foram positivas em PCR gêneroespecífica. A técnica de nested PCR espécie-específica foi significativamente mais sensível $(P<0,001)$ do que a PCR gênero-específica no sêmen e na urina de carneiros infectados experimentalmente. Em conclusão, a nested PCR espécie-específica desenvolvida neste estudo pode ser utilizada como ferramenta de diagnóstico para detecção de $\mathrm{B}$. ovis em sêmen e urina de carneiros suspeitos.

Palavras-chave: Brucella ovis, espécie-específica, nested PCR, sêmen, urina

\section{INTRODUCTION}

Ovine brucellosis caused by the Brucella ovis is a contagious disease, with venereal and oral transmission, which causes reproductive failure in rams. B. ovis, a Gram negative coccobacilli of $\alpha 2$ Proteobacteriacea family, can cause chronic epididymitis, orchitis and infertility in rams; whereas in ewes the infection uncommonly causes abortion and placentitis or birth of weak

Recebido em 17 de maio de 2011

Aceito em 25 de setembro de 2012

* Autor para correspondência (corresponding author)

E-mail: jane@fmvz.unesp.br 
lambs (Xavier et al., 2009). In addition to $B$. ovis, which has no zoonotic potential, ovine brucellosis can also be caused by $B$. melitensis, which is the most pathogenic Brucella species for humans (Blasco, 1990; Xavier et al., 2009). Therefore, a precise differential diagnosis between these two species of Brucella in rams is highly important (Xavier et al., 2010).

Currently, routine diagnostic tests for ovine brucellosis caused by $B$. ovis include clinical examination, serological tests, and bacteriology (Alton et al., 1988; Grilló et al., 1999). Some infected rams do not develop palpable lesions (Webb et al., 1980) or, conversely, have genital disease compatible with infection but have been exposed to different bacteria (Hughes e Claxton, 1968). The bacteriology of $B$. ovis is time consuming and not always efficient, because bacteria can be excreted intermittently in the semen of infected animals (Worthington et al., 1985; Baigun et al., 2000). Regarding serological tests, they generally fail in the sensitivity displayed. Due to the limitations exposed, the diagnosis of $B$. ovis infection is usually obtained by the association of two or more of these techniques.

More recently, PCR has been used as a diagnostic tool (Bricker, 2002). The diagnosis of $B$. ovis infection has been obtained through molecular amplification of respective DNA in samples. This technique demonstrated similar sensitivity when compared to bacteriology for $B$. ovis isolation (Manterola et al., 2003; Xavier et al., 2010). Furthermore, PCR allows a rapid identification of the pathogen in semen (Saunders et al., 2007; Xavier et al., 2010) or urine samples (Xavier et al., 2010) collected from infected rams. Xavier et al. (2010) recently developed a PCR based on the amplification of an open reading frame (ORF) specific for chromosome II of B. ovis (Tsolis et al., 2009) which has a remarkably good sensitivity when compared to bacteriological culture and has proven to be highly specific for detecting $B$. ovis infection. The authors demonstrated that the target sequence was conserved in 18 different $B$. ovis field strains and absent in other classical species of Brucella, in bacteria species that can cause epididimitis in rams, and in those microorganisms phylogenetically related to $B$. ovis (Xavier et al., 2010), confirming the specificity of the technique developed.
Nevertheless, its sensitivity may be lower than currently available genus-specific PCR protocols. Bricker and Halling (1994) developed a PCR based on the amplification of 711 insertion elements (IS711 or IS6501) present in multiple copies in the Brucella spp. genomes. The possibility of high sensitivity obtained by a molecular technique in which there are several copies of the target sequence of amplification led Manterola et al. (2003) to develop a diagnostic test for biological samples from sheep experimentally infected with Brucella ovis based on PCR assay with primers derived from the insertion sequence IS6501. Considering the specificity on the method described by Xavier $e t$ al. (2010), a pair of internal primers was delineated and the sensibility obtained through this species-specific nested PCR evaluated comparatively to the genus-specific PCR described by Manterola et al. (2003), with the goal of developing a highly sensitive speciesspecific nested PCR for the detection of $B$. ovis genomic DNA in semen and urine from rams experimentally infected with $B$. ovis.

\section{MATERIAL AND METHODS}

Fourteen 1-2 year-old rams were experimentally inoculated with B. ovis REO 198 strain, obtained from the "Instituto de Pesquisas Veterinárias Desidério Finamor" (Eldorado do Sul, RS, Brazil). Prior to inoculation, blood samples were collected for serological analysis, as well as semen and urine for culture and PCR, to confirm that the rams were free of $B$. ovis infection. All rams were purchased form a farm with no previous history of $B$. ovis infection. A suspension of $2 \times 10^{9} \mathrm{CFU} / \mathrm{mL} B$. ovis was inoculated $(2 \mathrm{~mL}$ intraprepucially and $50 \mu \mathrm{L}$ through the conjunctival route). After inoculation, semen, urine and blood samples were collected every 7 days, for 180 days for PCR and serology. Urine samples were collected by blocking the breath of the animals for thirty seconds and semen from each animal was collected by eletroejaculation. This experimental protocol was approved by the School of Veterinary Medicine and Animal Science UNESP Committee in Animal Experimentation (Protocol 69/2008).

The semen and urine cultures from rams were carried out prior to inoculation and on the same days of collection. Samples of all animals were 
cultured in plates containing modified ThayerMartin agar and Brucella blood agar. Plates were incubated at $37^{\circ} \mathrm{C}$ with $5 \% \quad \mathrm{CO}_{2}$ for approximately 3-7 days. Suspect colonies were identified by Gram staining, positive urease test and catalase test, negative oxidase test, absence of $\mathrm{H}_{2} \mathrm{~S}$ production, nitrate reduction test and growth in the presence of thionine and basic fucsine.

Serum samples from experimentally infected rams were tested with agar gel immunodifusion (AGID). A kit was made up of bacterial cell wall (Instituto de Pesquisas Veterinárias Desidério Finamor, Eldorado do Sul, RS, Brazil). Gel was prepared using $1 \%$ agarose gel (Invitrogen, Brazil) diluted in $0.1 \mathrm{M}$ borate buffer. The reaction was carried out at $25^{\circ} \mathrm{C}$ in a dark chamber, and the reading was performed at 24 , 48 and 72 hours.

Semen and urine samples were collected every week from each experimentally infected ram and a monthly pool was done to perform the genusspecific and species-specific nested PCRs. Semen and urine were thawed and diluted in $500 \mu \mathrm{L}$ of Tris-EDTA (TE) buffer, $\mathrm{pH} 8.0$ (10mM Tris-HCL pH 8.0; 1mM EDTA pH 8.0), incubated at $80^{\circ} \mathrm{C}$ for 10 minutes, and centrifuged at $13,000 \mathrm{~g}$ for 15 minutes. The supernatant was discarded, the pellet obtained was consecutively washed 2-3 times and then eluted in $500 \mu \mathrm{L}$ of buffer solution containing TE, pH 8.0 (10mM Tris- $\mathrm{HCl} \mathrm{pH} 8.0,25 \mathrm{mM}$ EDTA, pH $8.0,100 \mathrm{mM} \mathrm{NaCl}), 50 \mu \mathrm{L}$ of SDS $10 \%$ and $10 \mu \mathrm{L}$ of proteinase $\mathrm{K}(20 \mathrm{mg} / \mathrm{mL})$ and incubated at $37^{\circ} \mathrm{C}$ for 24 hours. The remaining extraction was made using the phenol/chloroform/isoamyl alcohol protocol (Cortez et al., 2001), and the final precipitate was resuspended in $30 \mu \mathrm{L}$ of $\mathrm{TE}, \mathrm{pH} 8.0$, and incubated at $56^{\circ} \mathrm{C}$ for 30 minutes.

For positive control, cultures of Brucella ovis were extracted, adding a colony of bacteria in $400 \mu \mathrm{L}$ of TE $\mathrm{pH} 8.0$ and following the protocol described for semen and urine extraction. The pellet obtained was then resuspended in $100 \mu \mathrm{L}$ of TE, $\mathrm{pH} 8.0$.

The present study used PCR with a primer pair targeting the IS711 sequence (ISP1: 5'GGTTGTTAAAGGAGAACAGC-3' and ISP2: 5'-GACGATAGCGTTTCAACTTG -3') present in multiple copies in the Brucella spp. genomes (Manterola et al., 2003). PCR reaction and cycle parameters were performed as previously described (Manterola et al., 2003) and a volume of $2.5 \mu \mathrm{L}$ of template DNA was added per PCR reaction. PCR products were resolved by $2 \%$ agarose gel electrophoresis. Reactions were considered positive when they yielded products of $700 \mathrm{bp}$.

Nested PCR amplified products were obtained from species-specific PCR. Speciesspecific PCR used a primer pair targeting the ORF AO503 (F: 5'ATCCCCCCATCACCATAACCGAAG-3' and R: 5'-GCCTACGCTGAAACTTGCTTTTG-3') located in the B. ovis-pathogenicity island 1 (BOPI-1) (Tsolis et al., 2009; Silva et al., 2011) as previously described (Xavier et al., 2010). PCR reaction and cycle parameters were performed as previously described (Xavier et al., 2010) and a volume of $2.5 \mu \mathrm{L}$ of template DNA was added per reaction. Nested PCR used a primer pair targeting an internal sequence of the ORF 503 (F NO503: 5'-CAACCACCCAAGTGTCAGTG-3' and R NO503: 5'-ATGGGATTTGCGATCCTGA-3'). Nested PCR reactions were performed using 12,5 mols of each primer at $25 \mu \mathrm{M}, 1.25 \mathrm{U}$ of Taq Polymerase (Invitrogen, Brazil), $23 \mu \mathrm{L}$ of a commercial PCR mix (PCR Supermix, Invitrogen), containing $22 \mathrm{mM}$ Tris- $\mathrm{HCl}(\mathrm{pH}$ $8.4), 55 \mathrm{mM} \mathrm{KCl}, 1.65 \mathrm{mM} \mathrm{MgCl}_{2}, 220 \mu \mathrm{M}$ dGTP, $220 \mu \mathrm{M}$ dATP, $220 \mu \mathrm{M}$ dTTP, $220 \mu \mathrm{M}$ dCTP, 22U recombinant Taq DNA Polymerase $/ \mathrm{mL}$, and stabilizers, and adding $2.5 \mu \mathrm{L}$ of the previous PCR product. Cycling parameters were denaturation at $95^{\circ} \mathrm{C}$ for 5 minutes; 35 cycles of denaturation $\left(95^{\circ} \mathrm{C}\right.$ for 1 minute), annealing $\left(55^{\circ} \mathrm{C}\right.$ for 1 minute), and extension $\left(72^{\circ} \mathrm{C}\right.$ for 1 minute); and a final extension at $72^{\circ} \mathrm{C}$ for 5 minutes. Nested PCR products were resolved by $2 \%$ agarose gel electrophoresis and reactions were considered positive when they yielded products of $171 \mathrm{bp}$. Positive and negative controls were used by adding $B$. ovis DNA genome and TE, respectively, in PCR and Nested PCR.

The frequencies of $B$. ovis detection by genusspecific PCR and species-specific nested PCR were compared by McNemar chi-square. The proportion of the agreement between diagnosis techniques was assessed with the Kappa test. 


\section{RESULTS AND DISCUSSION}

To test the sanitary status of rams, culture and PCR of semen and urine, and serology were performed prior to inoculation, and all results were negative.

Each one of the experimentally infected rams was serologically positive in at least one timepoint post infection. Antibody titers were detected by AGID in all animals in the third week after inoculation, decreasing soon after the fifth week, remaining variable as time passed, which confirms that the experimental challenge resulted in infection in all rams. The serological results are in accordance with previous reports, in which antibody titers were detected between 2 to 9 weeks after intraprepucial inoculation of $B$. ovis, and then became intermitent (Webb et al., 1980; Xavier et al., 2010)

In semen samples, the positivity of the speciesspecific nested PCR was 50.6\% (42/83), which was significantly different from the genusspecific PCR $(\mathrm{P}<0.001)$ which had a positivity rate of $27.7 \%$ (23/83) (Figure 1). Similarly, when the urine samples were subjected to speciesspecific nested PCR, the percentage of positive samples was $65.3 \%$ (49/75), which was significantly higher $(\mathrm{P}<0.001)$ than that obtained by genus-specific PCR, which detected $14.6 \%$ $(11 / 75)$ of positive samples (Figure 1). Xavier at al. (2010) detected B. ovis DNA by speciesspecific PCR in $17.9 \%$ and $19.7 \%$ semen and urine samples, respectively, from experimentally infected rams. Thus, the species-specific nested PCR demonstrated higher positivity when compared to genus-specific PCR and improved the sensitivity of the species-specific PCR method.

Species-specific nested PCR and genus-specific PCR had an agreement of $65 \%$ and $46.6 \%$, for semen and urine samples, respectively. Kappa test values were 0.3 for semen and 0.1 for urine, considered fair and poor agreements, since nested PCR detected a higher number of positive samples when compared to the genus-specific method (Table 1).

In this study, considering species-specific nested PCR results for semen and urine collected from the same experimental infected rams at a given time-point, the detection of $B$. ovis DNA in at least sample (i.e. semen and/or urine), reached $81.4 \%$ (59/72) (Figure 2). As semen samples are usually the specimen of choice for detection of B. ovis DNA by PCR (Manterola et al., 2003; Saunders et al., 2007), and B. ovis excretion in semen from rams is known to be intermittent (Hughes and Claxton, 1968; Manterola et al., 2003; Saunders et al., 2007, Xavier et al., 2010), urine is a valuable specimen from rams suspected to have the infection. Our results are in agreement with those obtained by Xavier et al. (2010), who demonstrated that the frequency of positive rams was higher when more than one biological sample was considered for diagnosis.

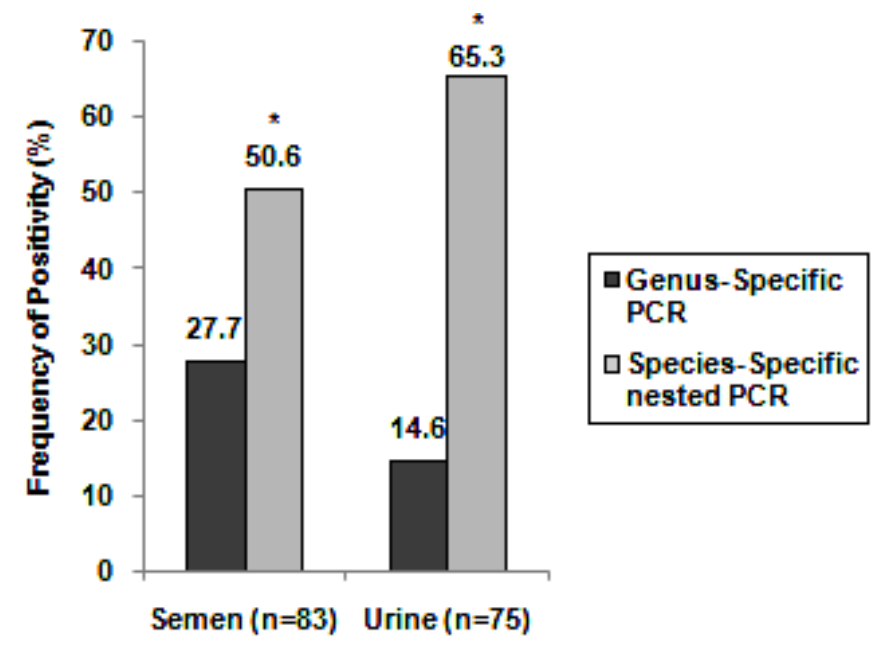

Figure 1. Frequency of positivity (\%) of Brucella ovis detection by genus-specific PCR and speciesspecific nested in semen and urine samples from experimentally infected rams with the REO 198 strain $(* \mathrm{P}<0,001)$. 
Table 1. Frequency (\%) of Brucella ovis detection by genus-specific PCR and species-specific nested PCR in semen and urine from experimentally infected rams with REO 198 strain, and frequency (\%) of agreement and kappa test value

\begin{tabular}{|c|c|c|c|c|}
\hline \multirow[b]{2}{*}{ Samples } & \multicolumn{3}{|c|}{ Method } & \multirow[b]{2}{*}{ Kappa } \\
\hline & $\begin{array}{l}\text { Genus-Specific } \\
\text { PCR }(\%)\end{array}$ & $\begin{array}{l}\text { Species-Specific } \\
\text { Nested PCR (\%) }\end{array}$ & Agreement (\%) & \\
\hline Semen & 27.7 & $50.6 *$ & 65.0 & 0.3 \\
\hline Urine & 14.6 & $65.3 *$ & 46.6 & 0.1 \\
\hline
\end{tabular}

*There was a statistically significant difference between genus-specific PCR and species-specific nested PCR (McNemar chi-square, $\mathrm{P}<0,001$ ).

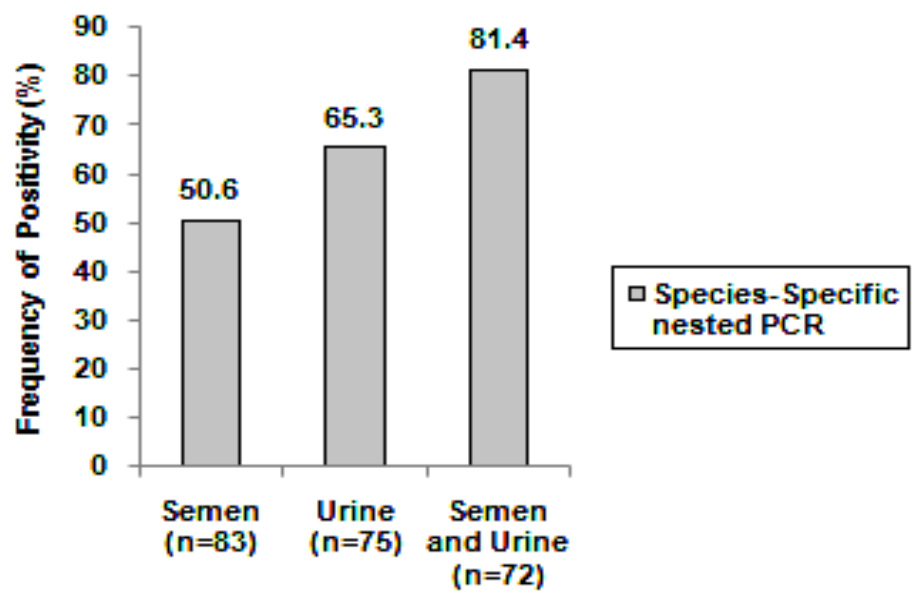

Figure 2. Frequency of positivity (\%) of Brucella ovis detection by specie-specific nested PCR in semen, urine, and semen and urine combined collected from experimentally infected rams with REO 198 strain.

Six and seven experimentally infected rams were positive by bacteriology in at least one time point during the course of the infection in semen cultures and urine samples, respectively. All experimentally infected rams had B. ovis DNA detected by analysis of specie-specific nested PCR in semen in at least one time point of infection. Regarding urine, 13 animals were positive using this technique. By genus-specific PCR, 11 and 7 experimentally infected rams were considered positive for infection based on the results obtained from semen and urine samples, respectively. In this study all PCR were conducted including negative controls, which were never positive, therefore indicating the absence of cross contamination, which supports the notion that the nested PCR can be routinely used in a diagnosis laboratory. The results of this study are in agreement with previous reports that nested PCR has an increased sensitivity for the diagnosis of infections caused by Brucella spp. (Baily et al., 1992; Herman, 1992; Romero et al., 1995; Da Costa et al., 1996).

\section{CONCLUSIONS}

The species-specific nested PCR developed in this study allowed the detection of $B$. ovis genomic DNA in semen and urine of rams and demonstrated improvement in the sensitivity of diagnosis. Thus, the species-specific nested PCR is a tool that can be implemented routinely as a specific and sensitive diagnostic method for Brucella ovis infection in rams.

\section{ACKNOWLEDGEMENTS}

This work was supported by FAPESP (Fundação de Amparo a Pesquisa do Estado de São Paulo, São Paulo, Brazil). LFC, RLS and JM are recipients of fellowships from $\mathrm{CNPq}$ (Conselho Nacional de Desenvolvimento Científico e Tecnológico, Brasília, Brazil). Work in the RLS lab is supported by CNPq and FAPEMIG (Fundação de Amparo a Pesquisa do Estado de Minas Gerais, Belo Horizonte, Brazil). Work in the JM lab is supported by CNPq and FAPESP. RLS is currently a fellow of the John Simon Guggenheim Memorial Foundation. 


\section{REFERENCES}

ALTON, G.G.; JONES, L.M.; ANGUS, R.D. et al. Techniques for the Brucellosis Laboratory. INRA, 1988.

BAIGUN, R.; CONIGLIARO, A.S.; LUNA, F. Aislamiento de Brucella ovis y control de reaccionantes serológicos en epididimitis ovina. Vet. Argent., v.17, p.103-107, 2000.

BAILY, G.G.; KRAHN, J.B.; DRASAR, B.S. et al. Detection of Brucella melitensis and Brucella abortus by DNA amplification. J. Trop. Med. Hyg., v.95, p.271-275, 1992.

BLASCO, J.M. Brucella ovis. In: NIELSEN, K.; DUNCAN, J.R. Animal Brucellosis. CRC Press, 1990. p.351-378.

BRICKER, B.J. PCR as a diagnostic tool for brucellosis. Vet. Microbiol., v.90, p.435-446, 2002.

BRICKER, B.J.; HALLING, S.M. Differentiation of Brucella abortus bv. 1, 2 and 4, Brucella melitensis, Brucella ovis and Brucella suis bv. 1 by PCR. J. Clin. Microbiol., v.33, p.1640-1642, 1994

CORTEZ, A.; SCARCELLI, E.; SOARES, R.M. et al. Detection of Brucella DNA from aborted bovine foetus by polymerase chain reaction. Aust. Vet. J., v.79, p.500-501, 2001.

DA COSTA, M.; GUILLOU, J.P.; GARINBASTUJI, B. et al. Specificity of six gene sequences for the detection of genus Brucella by DNA amplification. J. Appl. Microbiol., v.81, p.267-275, 1996.

GRILLÓ, M.J.; MARÍN, C.M.; BARBERAN, M. et al. Experimental Brucella ovis infection in pregnant ewes. Vet. Rec., v.144, p.555-558, 1999.

HERMAN, L.; DE RIDDER, H. Identification of Brucella spp. by using the polymerase chain reaction. Appl. Environ. Microbiol., v.58, p.2099-2101, 1992.

HUGHES, K.L.; CLAXTON, P.D. Brucella ovis infection. 1. An evaluation of microbiological, serological and clinical methods of diagnosis in the rams. Aus. Vet. J., v.30, p.201-203, 1968.
MANTEROLA， L.; TEJERO-GARCES, A.; FICAPAL, A. et al. Evaluation of a PCR test for the diagnosis of Brucella ovis infection in sêmen samples from rams. Vet. Microbiol., v.92, p.6572, 2003.

MATRONE, M.; KEID, L.B.; ROCHA, V.C.M. et al. Evaluation of DNA extraction protocols for Brucella abortus pcr detection in aborted fetuses or calves born from cows experimentally infected with strain 2308. Braz. J. Microbiol., v.40, p.480-489, 2009.

ROMERO, C.; GAMAZO, C.; PARDO, M. et al. Specific detection of Brucella DNA by PCR. $J$. Clin. Microbiol., v.33, p.615-617, 1995.

SAUNDERS, V.F.; REDDACLIFF, L.A.; BERG, T. et al. Multiplex PCR for the detection of Brucella ovis, Actinobacillus seminis and Histophilus somni in ram semen. Aust. Vet. J., v.85, p.72-77, 2007.

SILVA, T.M.A.; PAIXÃO, T.A.; COSTA, E.A. et al. Putative ATP-binding cassette transporter is essential for Brucella ovis pathogenesis in mice. Infection and Immunity, v.79, p.17061717, 2011.

TSOLIS, R.M.; SESHADRI, R.; SANTOS, R.L. et al. Genome degradation in Brucella ovis, corresponds with narrowing of its host range and tissue tropism. PLoS One, v.4, p.1-9, 2009.

WEBB, R.F.; QUINN, C.A.; COCKRAM, F.A. et al. Evaluation of procedures for the diagnosis of Brucella ovis infection in rams. Aust. Vet. J., v.56, p.172-175, 1980.

WORTHINGTON, R.W.; STEVENSON, B.J.; LISLE, G.W. Serology and semen culture for the diagnosis of Brucella ovis infection in chronically infected rams. N. Z. Vet. J., v.33, p.84-86, 1985.

XAVIER, M.N.; COSTA, E.A.; PAIXÃO, T.A. et al. The genus Brucella and clinical manifestations of brucellosis. Cienc. Rural., v.39, p.2252-2260, 2009.

XAVIER, M.N.; SILVA, T.M.A.; COSTA, E.A. et al. Development and evaluation of a speciesspecific PCR assay for the detection of Brucella ovis infection in rams. Vet. Microbiol., v.145, p.158-164, 2010. 